\title{
Cost Efficiency of the Oil and Gas Industry in Nigeria: Data Envelopment Analysis.
}

\author{
Tafamel, Ehiabhi Andrew Ph.D \\ The Department of Business Administration, Faculty of Management Sciences \\ University of Benin, Benin City, Nigeria
}

\author{
Akrawah, Onutomaha Dennis \\ The Department of Accounting, Faculty of Social Sciences \\ Ambrose Alli University, Ekpoma, Edo State, Nigeria
}

\begin{abstract}
In this study, we investigated the profitability and cost efficiency of oil and Gas companies in Nigeria from 2012-2013. This study used a sample of 9 quoted Oil and Gas companies in Nigeria that have consistently published their audited annual financial report between the periods under study. We adopted a Data Envelopment Analysis to test the efficiency of the various companies under Variable Returns to Scale (VRS), Constant Return to Scale (CRS) and Scale efficiency. In analyzing the inputs outputs further, we conducted descriptive statistics and correlation analysis. The Results show that Caverton Offshore Plc, Eternal Oil and Gas, Japaul Mobile and Total are good benchmarks in the oil and Gas industry in Nigeria were all efficient in the Scale efficiency test. Also Oando is scale efficient though it was not in the case of CRS. This study revealed that that only the very big oil and gas companies will have enough inputs to generate revenue and gross profit. The study recommended that management and concerned authorities of the oil and gas companies in Nigeria should implement sound policies that would ensure that the sector is efficient. It is therefore suggested that more resources should allocate for the oil and gas sectors for more returns with improved cost efficiency.
\end{abstract}

Keywords: Oil and Gas industry, Cost Efficiency, Data Envelopment Analysis, Labour and Capital, profitability.

\section{INTRODUCTION}

The oil and gas industry is the heart of any given economy ((Onwe, 2012). The Industry plays a crucial role to the sustainability of the economic and development of the Nigeria's power sector (Odulari, 2008). The oil and gas industry in Nigeria is made up of the upstream and downstream activities. The upstream oil and gas activities ideal with operations, exploration and Production (E \& P) of oil while the downstream activities involve the marketing and distributions of the products (Nwosu, Nwachukwu, Ogaji \& Probert, 2007). More so, the downstream sector is very crucial to the nation, as petroleum products constitute a key source of energy used for various purposes (Obasi, 2003). The cost efficiency strategy was based on the nature, strength, and direction and mix elements in the given premise (Osuagwu, 2004). However, achieving profitability and efficient cost management strategy is difficult especially in a sector like the oil and gas, as a result of the ambiguity and instability of environmental factors. An effective cost management in the upstream and downstream companies are very paramount to the success and failure of the oil and gas industry in Nigeria irrespective of the challenging business environments in the sector (Osuagwu, 1999). 
The government has invested huge sums of money in the servicing of the oil and gas industry. Majority of the amounts invested in the sector are repatriated abroad, where most of the equipment is manufactured; and providing employment opportunities for citizens of other countries. The presence of low local content greatly affects the operational efficiency of the industry. The poor operational efficiency is because most of the service contracts are awarded to foreign firms because local indigenous firms lack the requisite skills, technical expertise, manpower and production capacity and capability to compete favourably (Oladele, 2001). In addition, capital inefficiency in the petroleum sector and structural deficiencies are associated with poor training and low managerial ability (Aneke (2002)

Researcher's efforts in this sector of Nigerian economy were based on macro issues that looked at company's structure and strategies and performance indicator which include market share, growth, efficiency with little or no attention to the companies on the micro level (Azaiki \& Shagari, 2007; Okolo, 2006). In addition, studies in Nigeria economy in the last decade show that companies in the oil and gas industry have been playing a dominant role and occupy a strategic position in the economic development of Nigeria. Therefore, this study seeks to add to existing body of knowledge by focusing on the oil and gas companies in Nigeria by employing Data Envelopment Analysis (DEA) analysis to significantly examine the cost efficiency of the oil and gas sector.

\section{OBJECTIVES OF THE STUDY}

The broad objective of this study is to examine the cost efficiency of the oil and gas industry in Nigeria using Data Envelopment Analysis (DEA) in the oil and gas sector of Nigeria. Therefore, the specific objectives are as follows:

I. To investigate the extent of technical efficiency of oil and gas industry in Nigeria.

II. To investigate the extent of scale efficiency of oil and gas industry in Nigeria.

III. To investigate the operational efficiency of the oil and gas industry in Nigeria.

\section{Overview of the Oil and Gas Industry in Nigeria}

\section{LITERATURE REVIEW}

The oil and gas sector in Nigeria is the engine of growth and development of the entire economy (Onwe, 2012). The Nigerian economy was classified as mono-economy based on the fact the country depend on the contribution of oil sector to national development on the area of foreign exchange earnings, income generation, industrialization (Onwe, 2012). The revenues generated by the federal government in Nigeria from oil and gas sector give the country an absolute advantage to fund disbursements on various capital projects within the level of governments (Azaiki \& Shagari, 2007). The sector had experienced several industrial crises over the years arising from interests and crises emanating from the Niger Delta area (Ogbeifun, 2008). The upstream section of the industry had been constrained by the presence of expatriate quota abuse, non-implementation of collective agreements entered and unfair labour practices such as actualization, outsourcing, contract staffing and various forms of labour flexibility (Ogbeifun, 2008). There has been a general decline in the capacity utilization of the sector and government efforts to diversify the economy from mono-economy in terms of national income contribution had not yielded positive significant results (Akinwale, 2012).

The petroleum industry in Nigeria was made up of the upstream, downstream and the service sectors. Therefore, the upstream sector rendered services on mining, exploration, production and exportation and the sector was dominated by multinational companies such as Chevron, Shell, Agip, Elf, Texaco, Esso-Mobil inter alia belong to the upstream sector (Onwe, 2012). Though, Nigeria had be affected by price instability of the oil price in international market and 
this prompted OPEC's to made decision on the reduction of oil production. The government's policy on privatization gives indigenous entrepreneurs the right to participate in the oil exploration activities (Onwe, 2012).

\section{The Concept of Cost Efficiency}

Cost efficiency requires starts from the productive efficiency, so that, for a given state of technology, output is measured at the lowest possible cost (Kumbhakar \& Lovell, 2003). The distributional efficiency that is, output is distributed in such a way that society would not wish, given income and market prices, to spend resources in any other different way. According to Hollingsworth and Parkin (1998), efficiency is the distribution of available resources that be used in the utilization the given input in a productive setting. Therefore, the methods of estimating production functions in other to properly reflect efficiency which attempt to fit functions which bound the data from above (to varying degrees). If the distance of an observed point for a particular firm, lies below the estimated production frontier it is then often interpreted as the technical inefficiency of the firm. This means that if input output result of the oil and gas company occurs below the production possibility frontier, such a company is said to be operating at a technically inefficient level. There are many perspectives through which efficiency can be considered. Labour and capital in the productive process accelerated the sustainable development in any nation especially in the petroleum in industry in Nigeria. Meanwhile, the present incapacity for modern development is on the failure to invest and develop her human resources, often referred to as human capital (Anya, 2010). In addition, labour and human resource development is the process of developing the skills, knowledge and the capabilities of all the people of the society and which are needed in the labour market for the production of goods and services. The aggregate production function from intercountry data, strengthened speculations that human capital is an important determinant of modern economic growth and a critical factor in explaining the convergence in growth across countries (Risikat \& Dauda, 2010).

\section{Measurement of Cost Efficiency}

Data Envelopment Analysis (DEA) is a statistical technique used in measuring efficiency of a given units and also used to provide meaningful answers to on inputs and outputs. Charnes, Cooper and Rhodes developed the technique in the year 1978 and this application was used in Europe and the United States. Data envelopment analysis is a non-parametric technique for evaluating the technical efficiencies of a collection of Decision Making units (DMUs) (e.g. bank branches, Crown Health Enterprises) which consume common inputs to generate common outputs (Charnes, Cooper, Lewin \& Seiford, 1994). In DEA, the efficiency of a Decision-Making Unit (DMU) is measured relative to all other DMUs with a simple restriction that all DMU lie on or below efficient frontiers. The DEA technique is used to create a frontier set by efficient oil and Gas Companies and compares it with inefficient oil and Gas Companies to produce efficiency scores. One advantage of DEA is that it can handle multi dimensional problems with multiple input and output indices (variables). This feature makes DEA an advantageous performance evaluation tool widely adopted in various fields. Also, DEA avoids the difficulty of deciding for potentially unequal weights for the criteria. For problems involving Multi-Criteria Decision Making (MCDM), the allocation of weights (to show the varying importance levels for criteria) can be controversial. DEA technique uses the weight for each input and output that will let each DMU reach its maximum possible efficiency value (Charnes, Cooper, Lewin \& Seiford, 1994).

Furthermore, DEA is a mathematical optimization technique used to determine the efficiency of each units/section in an organization by maximising the ratio of a weighted sum of its 
outputs to a weighted sum of its inputs while ensuring that the efficiencies of other units do not exceed 100\%. Thus, a set of weights are determined for each unit in the best possible platform that imposes a uniform set of weights on all units (Julie, 2010).

\section{Technical efficiency}

Technical efficiency is achieved when the firm is able to produce a maximum level of outputs given a certain level of inputs or minimized inputs given a certain level of outputs (Kumbhakar \& Lovell (2003). Specifically, oil and gas companies are expected to achieve a specified level of output with the available amount of inputs contributed to such a process. In relating this to manufacturing companies, Koopmans(1999) observes that a manufacturing company is seen as technically efficient if it is impossible to produce more of an output without producing less of some other outputs or using more of some inputs (Mokhtar, AlHabshi, \& Abdullah, 2006). In other words, there is no wastage incurred in its manufacturing process.

The measurement of technical efficiency is premised on a description of production technology. The latter can be represented using isoquants, production functions, profit functions, or cost functions. Although the premises of these different approaches differ, the methodologies are fundamentally similar, and as such, their results are expected to converge.

\section{Scale efficiency}

The scale efficiency measure helps to determine inefficiency due to the input/output configuration as well as the size of operations. This allows for proper insight into the source of inefficiencies. The measure is obtained by estimating the efficient frontier under the assumption of variable returns-to-scale. It is a measure of scale efficiency without technical efficiency and purely reflects the managerial performance to organize the inputs in the production process (Bdour \& Al-khoury, 2008). Thus, this measure has been used as an index to capture managerial performance. In most cases, scale economies will appear as a technical inefficiency-points lying off the technically efficient unit production function when production occurs somewhere other than the most scale efficient level (Koopmans \& Debreu, 1957). With constant returns to scale assumption, one could examine the varying levels of technical efficiency over different scales of production to examine scale economies.

\section{Labour and Capital Efficiency of the Oil and Gas Sector}

Labour is one of the factors of production that are used for creation of wealth and other natural resources (Yesufu, 2000). Productivity is of great relevance to the employees that constitute the labour employed in a productive sector and to an organization whether commercial or not and to the national economy at large and accordingly therefore, to the upliftment of the welfare of the citizen and the reduction if not total eradication of mass poverty (Akinyele, 2007). Human capital development is the investment on education, training and re-training, and investment by individuals of time and money in their own development (Augusto, 2007). Labour and capital in the productive process accelerated the sustainable development in any nation especially in the petroleum in industry in Nigeria. Meanwhile, the present incapacity for modern development is on the failure to invest and develop her human resources, often referred to as human capital (Anya, 2010). The aggregate production function from intercountry data, strengthened speculations that human capital is an important determinant of modern economic growth and a critical factor in explaining the convergence in growth across countries (Risikat \& Dauda, 2010).

Odularu (2008) examined labor, capital, real gross domestic product, domestic crude oil consumption and crude oil export in Nigeria, the period of his study like some other previous 
ones were different from this study. The study revealed the effects of petroleum income on the Nigerian economy from 2000 to 2009.

\section{Operational and Cost Efficiency of the Oil and Gas Sector}

The Oil and gas company just like any other firm would be deemed efficient if it is operating on the production possibilities frontier. Cooper and Kaplan (1980) suggest that organizational costs are traceable to the bearing unit in which the resources are committed, and that all activities, in turn, are traceable to the operational lines that consume them. Cooper and Kaplan (1980) introduce the notion that activities drive costs. In other words, the oil and gas sector have successfully employed to improve operational performance. Cost of goods sold, sometimes abbreviated as COGS or called "cost of sales," is the direct cost of producing the product or service offered by your business. What do we mean by direct costs? Direct costs are limited to those costs that relate directly and obviously to the production of your product and service. This translates to the raw materials and direct labour used to bring the product or service into existence. Without these things, you wouldn't have a product or service to sell in the first place (Cooper, 2008) Operating costs includes both fixed costs and variable costs. Fixed costs, such as overhead, remain the same regardless of the number of products produced; variable costs, such as materials, can vary according to how much product is produced. According to Quirin, Berry and O'Bryan (2000) companies fundamental include cash flows, production efficiency, stock price appreciation potential and growth of the company.

Misund, Osmundsen and Asche (2007) conducted a study on Oil Company's structural shift in their valuation. They found out that net income, cash flows and accruals and the size of oil and gas reserves are the instrumental variables that significantly influence structural shift in the oil and gas companies.

A study conducted by Marcel and Mitchell (2006) on the operational efficiency of Saudi Aramco, Kuwait Petroleum Corp, the National Iranian Oil Company, Sonatrach of Algeria, and the Abu Dhabi National Oil Company. They conducted the study in the Middle East and they employe a survey research design by interviewing 120 executives and managers. Their empirical findings revealed that there is a balance between profitability and cost effectiveness of the oil companies.

\section{Profitability and Cost Efficiency of the Oil and Gas Sector}

Profitability represents a as output of activity, and the appropriate measure selected to assess corporate performance is considered according to the organization type and objectives of evaluation (Ostroff \& Schmidt, 1993). Profitability is an essential prerequisite for an increasing competitiveness of a company that operates in a globalized market especially in the oil and gas industry. Eller, Hartley and Medlock (2011) conducted a study on cost efficiency of NOCs and OICs. They found out that are OICs more efficient compared to NOCs. Their level of efficiency was claim that much of differences between these companies are owing to the based on the institutional characteristics of the companies. Saleem and Rehman (2011) study on the influence of liquidity factors on profitability of the oil and gas companies showed that there is a significant relationship between ROA and profitability in oil and gas companies in Pakistan. Taheri (2011) examined the effective factors on the market value of five major oil companies. Market value is an important indicator in oil and gas industry. The profit and oil and gas reserves of oil companies effectively influence the market value. The results of study showed that oil and gas reserves of international oil companies are more effectively influencing market value than the oil and gas profit. Victor (2007) also examined the market value of NOCs and 
IOCs as a function of the total production, the company income and the company labour force, and came to this result that the size of labour force has no effect on the company market value.

Talevski and Lima (2009) examined a national oil company in Brazil to measure its potential to create shareholders" value and stock fail value by the end of 2008. Oil and gas companies have multidimensional performance, with earnings, cash flows and changes in reserves. Arong, Ezugwu and Egbere (2014) examine the effects of environmental cost management on the profitability of oil sector in Nigeria from 2004 to 2013. The data employed foe the study were collected from the Central Bank of Nigeria (CBN). Result from the multiple regression analytical technique revealed that there exists a significant relationship between influences of environmental cost management and the profitability of oil sector in Nigeria. Misund, Osmundsen and Asche (2007) examined a number of oil companies in terms of structural shift in their valuation. They mentioned that financial figures such as net income, cash flows and accruals, and operational measures such as the size of oil and gas reserves have become more important in the equity valuation process for oil and gas companies during the 1990s and are instrumental in explaining this structural shift

\section{METHODOLOGY}

This study adopted ex post facto and longitudinal research design. The choice was premised on the non-controllability and non-manipulability of the independent variables well as the time frame of 2011 - 2013. In this research, the population consists of seven Oil \& Gas companies in Nigeria. The study was subjected one broad model category. The model will focus on performance efficiency of capital and labour using DEA input-oriented CCR model

\section{DEA input-oriented CCR model}

The formulation developed by Charnes, Cooper and Rhodes (1978) uses linear programming to extend Farrell's (1957) single output/single input efficiency measures to the multioutput/multi input case. The focus is to optimize the ratio of outputs to inputs by solving for a group of weights that satisfy a system of linear equations (Rouse, 1997). This was adopted for the study.

This study made use of the following inputs and outputs for the oil and gas companies in Nigeria.

\begin{tabular}{|l|c|}
\hline INPUTS(COST) & OUTPUT(PROFIT) \\
\hline & $\bullet$ GROSS PROFIT \\
$\bullet$ STAS & $\bullet$ PAT \\
$\bullet$ OPERATING COST & $\bullet$ ROE \\
& \\
\hline
\end{tabular}

In this study, the performance efficiency scores of selected oil and gas companies in Nigeria was computed by the DEA and the DEA Frontier Software was used to perform the calculation

\section{PRESENTATION AND ANALYIS OF RESULTS}

The study evaluated an average two year (2012-2013) efficiency score of nine oil and gas companies in Nigeria. The results obtained are presented as follows; The DEA models involved in assessing profitability and cost efficiency of nine oil and gas companies (9) using DEAFrontier software. The overall technical efficiency score (i.e. technical efficiency relative to the CRS DEA model) for each of the 9 oil and gas companies is presented in Table 1 . The CRS DEA model is based on the assumption of constant return to scale for all the oil and gas companies. 
Table 1: Technical efficiency scores of the 9 oil and gas companies based on CRS DEA model

\begin{tabular}{|c|l|r|}
\hline $\begin{array}{c}\text { DMU } \\
\text { No }\end{array}$ & $\begin{array}{l}\text { OIL AND GAS } \\
\text { COMPANIES }\end{array}$ & $\begin{array}{c}\text { INPUT } \\
\text { CRS } \\
\text { EFFICIENCY }\end{array}$ \\
\hline 1 & $\begin{array}{l}\text { CAVERTON OFFSHORE } \\
\text { PLC }\end{array}$ & 1.00000 \\
\hline 2 & CONOIL & 0.97552 \\
\hline 3 & ETERNAOIL & 1.00000 \\
\hline 4 & FORTE OIL (AP) & 0.96270 \\
\hline & \begin{tabular}{l} 
JAPAUL OIL $\quad 1.00000$ \\
\hline 5
\end{tabular} & MARITIME SERV PLC \\
\hline 6 & MOBIL NIG PLC & 1.00000 \\
\hline 7 & $\begin{array}{l}\text { MRS(TEXACO } \\
\text { CHEVRON) }\end{array}$ \\
\hline 8 & OANDO PLC & 0.96224 \\
\hline 9 & TOTAL NIGERIA PLC & 1.98150 \\
\hline \multicolumn{2}{|c|}{ Source: Author (2015) } \\
\hline
\end{tabular}

In Table1 above, it would be revealed that the technical efficiency scores that only five (5) Oil and Gas companies out of the 9 were efficient while 4 were found to be relatively inefficient in turning their inputs to relatively higher output. The five (5) efficient oil and gas companies that were able to use their input to generate better outputs as at 2012-2013 are; Caverton Offshore Plc, Eternaoil, Japaul Oil \& Maritime Service Plc, Mobil Nig Plc and Total Nigeria Plc. This means that these companies used fewer inputs to produce relative higher output compared to others as at 2012-2013. In the same results, we also found out that most old and big oil companies such as Oando Plc, Conoil, Forte Oil (AP), Mrs (Texaco Chevron), were found to be technically inefficient in converting their given inputs to outputs when compared to their counterparts.

The Variable Return to Scale DEA model is based on the assumption of variable return to scale for all the oil and gas companies and the result is presented below:

Table 2: Technical efficiency scores of the 9 oil and gas companies based on VRS DEA model

\begin{tabular}{|c|l|r|}
\hline $\begin{array}{c}\text { DMU } \\
\text { No }\end{array}$ & $\begin{array}{l}\text { OIL AND GAS } \\
\text { COMPANIES }\end{array}$ & $\begin{array}{c}\text { INPUT } \\
\text { VRS } \\
\text { EFFICIENCY }\end{array}$ \\
\hline 1 & $\begin{array}{l}\text { CAVERTON OFFSHORE } \\
\text { PLC }\end{array}$ & 1.00000 \\
\hline 2 & CONOIL & 0.99044 \\
\hline 3 & ETERNAOIL & 1.00000 \\
\hline 4 & FORTE OIL (AP) & 0.96933 \\
\hline 5 & $\begin{array}{l}\text { JAPAUL OIL } \\
\text { MARITIME SERV PLC }\end{array}$ \\
\hline 6 & MOBIL NIG PLC & 1.00000 \\
\hline 7 & $\begin{array}{l}\text { MRS(TEXACO } \\
\text { CHEVRON) }\end{array}$ \\
\hline 8 & OANDO PLC & 0.96372 \\
\hline 9 & TOTAL NIGERIA PLC & 1.00000 \\
\hline \multicolumn{2}{|c|}{ Source: Author (2015) } \\
\hline
\end{tabular}

Source: Author (2015) 
In Table 2, the study showed that technical efficiency scores that only six (6) Oil and Gas companies out of the 9 were efficient while 3 were found to be relatively inefficient in turning their inputs to relatively higher output. The Six (6) efficient oil and gas companies that were able to use their input to generate better outputs as at 2012-2013 and these companies were Caverton Offshore Plc, Eternaoil, Japaul Oil \& Maritime Service Plc, Mobil Nig Plc, Oando Plc And Total Nigeria Plc. This means that these companies used fewer relative inputs at their disposal to produce relative higher output compared to others as at 2012-2013. In the same results, we also found out that most old and big oil companies such as Oando Plc, Conoil, Forte Oil (AP), Mrs (Texaco Chevron), were found to be technically inefficient in converting their given inputs to outputs when compared to their counterparts. This result reveals also that only Oando moved from inefficiency in CRS to efficient using the VRS efficiency based analysis. Conoil, Forte Oil and MRS oil remained inefficient in both CRS and VRS. Other oil and Gas companies such as Caverton Offshore Plc, Eternal oil, Japaul, Mobil and Total remained efficient in both CRS and VRS efficiency evaluation.

The overall technical efficiency score (i.e. technical efficiency relative to the SCALE efficiency DEA model) for each of the 9 oil and gas companies is presented in Table 3 below.

Table 3: Scale efficiency scores of the 9 oil and gas companies in Nigeria based on DEA model

\begin{tabular}{|c|l|r|}
\hline $\begin{array}{c}\text { DMU } \\
\text { No }\end{array}$ & $\begin{array}{l}\text { OIL AND GAS } \\
\text { COMPANIES }\end{array}$ & $\begin{array}{r}\text { CRS/VRS } \\
\mathbf{2 0 1 2 - 2 0 1 3}\end{array}$ \\
\hline 1 & $\begin{array}{l}\text { CAVERTON } \\
\text { OFFSHORE PLC }\end{array}$ & 1.00000 \\
\hline 2 & CONOIL & 0.99044 \\
\hline 3 & ETERNAOIL & 1.00000 \\
\hline 4 & FORTE OIL (AP) & 0.96933 \\
\hline & $\begin{array}{l}\text { JAPAUL OIL \& } \\
\text { MARITIME SERV }\end{array}$ \\
\hline 5 & \begin{tabular}{l} 
PLC \\
\hline 6
\end{tabular} & MOBIL NIG PLC \\
\hline 7 & $\begin{array}{l}\text { MRS(TEXACO } \\
\text { CHEVRON) }\end{array}$ & 1.000000 \\
\hline 8 & OANDO PLC & 1.00000 \\
\hline 9 & $\begin{array}{l}\text { TOTAL NIGERIA } \\
\text { PLC }\end{array}$ \\
\hline
\end{tabular}

Source: Author (2015)

In Table 3, it was found that the scale efficiency scores six (6) Oil and Gas companies out of the 9 were scales efficient while 3 were found to be relatively scale inefficient in turning their inputs to relatively higher output when subjected to a tougher efficiency score. The Six (6) efficient oil and gas companies that were able to use their input to generate better outputs as at 2012-2013 were Caverton Offshore Plc, Eternaoil, Japaul Oil \& Maritime Serv Plc, Mobil Nig Plc, and Oando Plc And Total Nigeria Plc. This means that these companies used fewer relative inputs at their disposal to produce relative higher output compared to others as at 2012-2013. In the same results, we also found out that most big oil companies such as Oando Plc, was able to become efficient even when subjected to a tougher efficiency measure. Conoil, Forte Oil (AP), Mrs (Texaco Chevron), was found to be scale inefficient in converting their given inputs to outputs when compared to their counterparts. This result reveals that Conoil, Forte Oil and MRS oil remained inefficient in both CRS and VRS and Scale efficiency other oil and Gas companies such as Caverton Offshore Plc, Eternal oil, Japaul, Mobil and Total remained efficient in CRS, VRS and Scale efficiency evaluation. 
In examining the relationship among the variables we employed the Pearson correlation coefficients (correlation matrix) and the results are presented in Table 5

Table 4: Correlation Matrix

\begin{tabular}{lrrrrrr}
\hline \multicolumn{1}{c}{ COGS } & SOA EXP & STAFFCOST & TASSET & GPROFIT & REVENUE \\
\hline COGS & 1.000 & & & & \\
SOA EXP & 0.976 & 1.000 & & & & \\
STAFFCOST & 0.953 & 0.975 & 1.000 & & & \\
TASSET & 0.944 & 0.958 & 0.971 & 1.000 & & \\
GPROFIT & 0.971 & 0.996 & 0.984 & 0.962 & 1.000 & \\
REVENUE & 1.000 & 0.982 & 0.960 & 0.949 & 0.977 & 1.000 \\
\hline \multicolumn{7}{c}{ SOURCE: AUTHOR (2015) }
\end{tabular}

In Table 5, the study focused on the correlation among the variables. Firstly, the out puts (Gross profit and Revenue) are highly correlated because as more output is been generated, more of the inputs would be required which makes output and inputs to move in same direction. Gross profit shows high positive correlation between all out puts. Revenue also shows the same level of high positive correlation with all the inputs. The correlation between cost of sales and revenue are perfectly correlated (REVENUE; COGS=1). This shows that the major input that drives revenue in the sector is cost of sales. As the Revenue increases, more is spent to achieve such increase in revenue. It therefore suggests that any oil and gas company that wants to remain efficient in Nigeria must be able to effectively control its selling cost. These correlation results are not necessary for our hypotheses testing since they only measure association and not causality (impact). The full correlation matrix also revealed that the variables are highly correlated but this does not impact our result and its findings.

\section{DISCUSSION OF FINDINGS}

Results show that CAVERTON OFFSHORE PLC, Eternal Oil and Gas, Japaul Mobile and Total are good benchmarks in the oil and Gas industry in Nigeria as they were all efficient in the tougher Scale efficiency test. Also Oando is scale efficient though it was not in the case of CRS. This finding showed that of the 9 oil and gas companies in Nigeria, 6 are efficient jugging by scale efficiency, 6 by VRS and 5 by CRS. This implies that only $66 \%$ of our sampled oil and gas companies are efficient. This is consistent with the opinion of Bdour and Al-khoury (2008) that scale efficiency without technical efficiency and purely reflects the managerial performance to organize the inputs in the production process. Results showed that Conoil had a slack in its staff cost which showed a slowdown in their Gross profit. Forte oil showed a slack in their Total Asset which also affected their Gross profit. MRS showed a slack in their total Asset which affected their Gross profit. The result suggests that most of the slack in the non-efficient oil companies affect their Gross profit output. This is in consonance with the findings of Eller, Hartley and Medlock (2011) that National Oil Companies of the oil and gas companies are less cost efficient than International Oil Companies. It is therefore suggests that we should accept the hypothesis on the basis that oil and gas companies in Nigeria are profitable and cost efficient. CRS: In terms of constant return to scale, the hypothesis all oil and gas companies in Nigeria are not technically efficient based on constant returns to scale. This hypothesis holds true as only 5 out of 9 oil and Gas companies are efficient in converting their inputs to outputs within the sample period. VRS: In terms of variable returns to scale, hypothesis states that all oil and gas companies in Nigeria are not technically efficient based on variable returns to scale. Our results reveal that only 6 out of 9 oil and gas companies are efficient using the variable returns to scale efficiency score. This means that all oil and gas companies in Nigeria are not 
technically efficient based on variable returns to scale efficiency score. This is inconsistent with the findings of Al-Obeidan and Scully (1991) that state-owned enterprises (SOEs) oil and gas companies were only 61 to 65 percent as technically efficient as privately owned for-profit firms. It is therefore suggests that we should reject the hypothesis on the basis that oil and gas companies in Nigeria are technically efficient. This study revealed that that only the very big oil and gas companies will have enough inputs to convert to Revenue and Gross profit. A large input such as Assets, Staff Cost, and Cost of Sale will mean more ability to reduce waste and produce more output.

\section{CONCLUSION AND RECOMMENDATION}

The oil and gas industry in Nigeria comprises the upstream, the downstream and service sectors. The upstream sector focuses on mining, exploration, production and exportation and is dominated by multinational companies. Chevron, Shell, Agip, Elf, Texaco, Esso-Mobil inter alia belong to the upstream sector. Though, Nigeria appears to have been leading in OPEC's decisions on reduction of oil production as a necessary policy against persistent instability in the price of oil in the international oil market. Oil and gas companies are expected to achieve a specified level of output with the available amount of inputs contributed to such a process. The study recommended that management and concerned authorities of the oil and gas companies in Nigeria should implement sound policies that would ensure that the sector is technically efficient. It was recommended that oil and gas companies in Nigeria were profitable and cost efficient. Therefore, more resources should allocate for the oil and gas sectors for more returns with improved cost efficiency.

\section{References}

Akinyele, S.T (2007). Need satisfaction: An effective tool for workers commitment to work. Journal of Business and Management, 2 (1): 72-79.

Akinwale, Y.O (2012). Empirical analysis of resource curse in Nigeria. International Journal of Economics and Management Science, 1(6): 19-25.

Aneke, P. (2002). The role of major operators in the development of local content in the Nigerian oil and gas industry. A paper delivered during a national seminar on the dynamics of equipment leasing and contract financing for local contractors in the oil and gas sector, Port Harcourt, Nigeria.

Anya O.A (2010). Nigeria: The human capital challenge, African Journal of Physics, 3.

Augustus, N. G (2007). Human resources development and manpower in Nigeria, Godsidi Press Ltd.

Azaiki \& Shagari (2007). Oil, Gas and life in Nigeria, Ibadan, Y - Books, a Division of Associated Book - Makers Nigeria Limited.

Charnes, A, Cooper, W.W \& Rhodes, E (1978). Measuring the efficiency of decision making units. European Journal of Operations Research, 2, 429-444.

Farrell, M.J (1957). The measurement of productive efficiency. Journal of Royal Statistical Society, 120 (3), 11-48.

Nwosu, H. U, Nwachukwu I. N, Ogaji, S.O.T \& Probert, S.D. (2007). Local Harnessing in Crude Oil and Natural Gas in Nigeria in Applied Energy, 83 (11): 1274-1287.

Obasi, N. K. (2003). Foreign participation in the Nigerian Oil and Gas Industry sourced online: http://www.onlinenigeria.com/links/adv.asp?blurb=493

Ogbeifun, L.B. (2008). Labour crises in the oil and gas sector: Challenges to development in the oil and gas sector. Paper Presented at a Workshop Organised by NIM, Jos.

Odulari, G. O. (2008). Crude oil and the Nigerian Economic Performance. Oil and Gas Business.

(http://www.ogbus.ru/eng/).

Okolo, C. H. (2006). Nigerian content - expanding horizons. A paper presented at the Nigerian Oil and Gas Conference, Lagos Nigeria. Nigerian Content website documents: http://www.nigcontent.com/index.php. 
Taffamel, E. A., \& Akrawah, O, D. (2015). Cost Effieiency of the Oil and Gas Industry in Nigeria: Data Envelopment Analysis. Archives of Business Research, 3(6), 138-148.

Oladele, O. R. (2001). Opportunities for indigenous participation. Paper presented at the NNPC Workshop on Improvement of Local Content.

Onwe, O.J (2012). Economic implications of petroleum policies in Nigeria: An Overview. American International Journal of Contemporary Research, 2 (5).

Osuagwu, L (2004). Relationship marketing strategies in Nigerian companies, The Marketing Management Journal, 14(2): 114-128.

Osuagwu, L (1999). Marketing: Principles and Management, Lagos: Grey Resources Limited.

Risikat 0 \& Dauda S (2010). Role of human capital in economic development: An Empirical Study of Nigerian case. Culled from; www.gcbe.us/2010_obec/data/Risikat\%.

Yesufu TM (2000). The human factor in national development: Nigeria, Spectrum Books Limited, Ibadan, Nigeria 